\title{
Gothicizing Victorian Folklore: Spring-heeled Jack and the Enacted Gothic
}

Karl Bell, University of Portsmouth

\begin{abstract}
This article focusses on the Victorian bogeyman, Spring-heeled Jack, as a historicised example of the Gothic and folklore's cultural dialogue and divergences in nineteenth-century Britain. Variously described as a ghost, beast, or devil when he first terrorised Londoners in 1837-38, Spring-heeled Jack evolved from local folklore to press sensation to penny dreadful serials. These texts reworked his folkloric accounts through stories that were heavily indebted to earlier Gothic literature for many of their narrative tropes. The article uses this urban legend to explore what it terms the enacted Gothic; the eruption of folkloric and Gothic elements beyond the bounds of fiction and into Victorians' everyday lives. While encouraging Gothic scholarship to engage with folkloric 'texts', it argues that we need to look beyond obvious similarities to appreciate important distinctions arising from their differing natures, cultural functions, and modes of storytelling.
\end{abstract}

Key words - Folklore, Spring-heeled Jack, urban legend, enacted Gothic, penny dreadfuls 
That Gothic and folkloric narratives possess shared references to supernatural entities, threatening landscapes, and, underlying that, common plot motifs and recurring thematic conventions, is self-evident to anyone with an interest in darkly fantastical tales. The supposedly pre-literate, oral nature of folklore may encourage us to assume that Gothic literary texts have simply absorbed these older narrative tropes and structures. In a number of recent publications Manuel Aguirre has championed the significance of folklore in his critical study of the formal origins and structural poetics of the Gothic, stating that 'beyond its debt to literary and philosophical sources, Gothic derives from myth, legend and folktale'. ${ }^{1}$ While acknowledging Aguirre's contribution to this underdeveloped field of critical enquiry, this article proposes a more complex relationship of resonances, divergences, and appropriations in the nineteenth century, and in so doing moves beyond folklore as one of Gothic's sources of inspiration, origin and influence, to explore their ongoing dialogue and interaction in Victorian Britain.

Beginning with some rather broad, conceptual reflections on the connections and differences between Gothic and folkloric narratives, these issues will then be grounded through a historicised case study, that of the Victorian urban legend of Spring-heeled Jack. Variously described as a ghost, beast or devil when he first started to terrorise Londoners in the winter of 1837-38, his narrative gradually evolved from local gossip to brief press sensation, and later transformed into both folkloric accounts and Gothic-inflected penny dreadful serials. Coming in the wake of the first wave of Gothic literature, Spring-heeled Jack demonstrates how folklore can be seen to have responded to the Gothic as much as the other way round. While his legend demonstrates resonances and divergences between folkloric and Gothic narratives, it requires us to consider not a binary but a trinary between folklore, Gothic and his 'real' world existence. Spring-heeled Jack is used to explore what will be 
termed the enacted Gothic; the eruption of folkloric and Gothic elements beyond the bounds of fiction and narrative conventions, and into the everyday lives of Victorians.

Gothic scholarship has long overlooked folklore in favour of literary and visual media. Approaching the topic from the perspective of a cultural historian rather than a literary scholar, this article offers some important first steps in thinking about both the relationship between Gothic and folkloric narratives and the value of exploring their interactions in specific historical contexts. It argues that while we can recognise similarities and apparent connections, these should not overshadow the deeper, differing cultural functions of Gothic and folkloric narratives. While folklore should certainly be as open to Gothic criticism as any other form of supernatural narrative, the lines between them should not become so blurred as to blind us to their distinctive narrative operation and cultural purpose. It is these elements of these particular forms that lead this article to conclude that while folklore can certainly be subjectively inflected through a Gothic lens, it should not be understood as Gothic in itself. ${ }^{2}$

\section{Gothic and Folklore}

In exploring formal aspects of the Gothic genre, Manuel Aguirre situates folktales as a preexisting body of stories that subsequently informed the development of the Gothic. This progression from oral folklore to literary Gothic is rather too neat. When engaging with folklore the Gothic was drawing on something that was itself an organic, often haphazard series of earlier and ongoing interactions between literary and oral cultures. ${ }^{3}$ In this context, it is also important to distinguish between what Lauri Honko termed the different 'lives' of folklore. The first was largely unselfconscious, simply part of local oral culture. Its second 
life made it explicit by extracting it from that communal cultural context and transforming it into a literary summary for consumption by 'outsiders'. It is in its second, literary incarnation that folklore reached wider audiences beyond the immediate area in which it may have originated and circulated. ${ }^{4}$ In fairness, Aguirre recognises that folklore became embroiled in Gothic's evolution in a similarly indirect way, for folkloric narrative structures entered the genre via its early practitioners drawing upon literary texts - medieval romances and chivalric quests - which had their more distant origins in oral folk tales $(295-96) .{ }^{5}$ This article's examination of the legend of Spring-heeled Jack will emphasise how these oral and literary interactions continued into and throughout the nineteenth century too.

Within any given region one typically finds a rich store of folkloric narratives replete with seemingly familiar Gothic motifs - murders and ghosts, premature burials and the internment of the living, the restless dead, spirits and demons, the supernatural punishment of sinful behaviours, family curses, and buried secrets. ${ }^{6}$ Folklore often provides a dark and frequently bloody expression of the collective imagination, its relationship with local landscape transforming the environment into a text, a repository of communal memory and (mis)remembering. ${ }^{7}$ The Gothic's narrative tropes, motifs, settings and concerns are all echoed in folklore's own formulaic structures and story-telling conventions. ${ }^{8}$ One locates its reader in a Gothic story as surely as the other informs its audience that they are being told a folktale. However, it is not as a genre so much as a modality that the Gothic becomes entwined with folklore. The Gothic has proven itself remarkably able to inflect and transform other forms of narrative. As Simon Bacon notes, the Gothic can infuse different media and genres, and in so doing can alter a text, 'bringing to it a Gothic lens through which one can view and interpret the text anew'. ${ }^{9}$ As such, while supernatural folklore is not inherently 'Gothic' it can certainly succumb to the same infusion and colouring that the Gothic affects elsewhere, and should, therefore, be equally responsive to the application of Gothic criticism. 
The Gothic's ability to roam wherever it wishes, and seemingly without limit, resurrects concerns that it's ever-broadening cultural application risks weakening it into a vague sense of things just 'feeling Gothicky', thereby diluting its meaning and undermining its usefulness as a critical category (Warwick, 7-8). An attempt to incorporate folkloric narratives into the ambit of Gothic scholarship is to be welcomed, but it raises the issues of boundaries, of how to distinguish a Gothic(-inflected) folktale from the broader spectrum of storytelling that similarly draws upon the supernatural and fantastical to both frighten and entertain. One also needs to be sensitive to the teleological issue whereby folklore that may have preceded the advent of the Gothic, and may have formed its formal antecedents, becomes retrospectively colonised as Gothic.

While appreciating the resonances indicated above, and the Gothic's ability to inflect other narrative forms, those boundaries can be firmed up through recognising that folklore and the Gothic differ notably in the nature of their presentation, characterisation, and cultural function, and thus do not operate in the same way. If one were to formulate a crude but fundamental divide then it would be that folklore is often about 'selfing', Gothic about 'othering', although both necessarily contain a sense of their opposite as part of those definitions. Folklore informs the boundaries of communal inclusivity and exclusivity by marking out the initiated from the ignorant or uninformed. Its narratives, worldview and politics tend to operate most strongly at a local level. By contrast, the Gothic is orientated towards othering, be it peoples, places, or aspects of one's own personal or collective psychology. As the growth of a transnational Gothic has demonstrated, its power is certainly not limited to the local, although it is invariably coloured by local cultures. ${ }^{10}$

To further examine these distinctions it is worth exploring Sara Wasson's claim that 'the Gothic mode [... has] two core characteristics: a particular emotional colouring of the narrative filter, and a preoccupation with certain relationships to space. ${ }^{11}$ Folktales, like the 
Gothic, may evoke terrifying thrills through the supernatural and the macabre, but they are, by their common, identifiable everyman nature, usually devoid of the Gothic's emphasis on excess, angst, instability, and the overwrought (Botting, 3). Folkloric characters tend to be recognisable archetypes rather than developed individuals. Largely devoid of interiority, and usually presented with the detachment of the third person perspective, they stand in marked contrast to the distorted, unreliable subjectivity of Gothic's many first person narratives. Within the context in which folktales were exchanged this was a strength; their lack of psychological subjectivity and their generic patterns allowed them to be readily appropriated into any local context, to be both exchanged and easily recognised elsewhere. As such, folklore and the Gothic tend to have a different emphasis when it comes to psychology, for while Gothic criticism has tended to favour Freudian psychoanalysis, folklore arguably has closer affinities to Jungian notions of mythic archetypes. ${ }^{12}$ While David Punter has referred to the Gothic as 'a literature of psychic grotesquerie', folktales, by contrast, tend to suggest a rather humble, plebeian mentality grounded in mundane needs and desires. ${ }^{13}$ Similarly, folkloric ghost stories frequently provide the matter-of-fact mechanics of murders and suicides, stripped, in most cases, of the Gothic's self-indulgent gloom.

Taking Wasson's second characteristic, while the Gothic has been described as a literature of 'self-conscious un-realism' (Punter, 4), folklore typically imagines the supernatural as enmeshed within and accessible through the mundane world. Witches, spirits, and faerie folk dwell in known places within the landscape, terrains that in many cases were said to have been shaped by the legendary actions of giants or even the Devil. Such tales form part of a community's local comprehension and imaginative ordering of their spatial surroundings for they are more often about defining than defying supernatural boundaries. While the latter is demonstrated in such tales, that imagined transgression is presented as a warning that the tale encourages its audience to heed. As Ulo Valk has noted, legends are firmly linked to the 
spaces and socio-economic realities inhabited by their tellers and audiences. In colouring how their localised environment is known, understood, and remembered, 'the legend shapes

collective mental attitudes and supports the local identities of village communities' ${ }^{14}$ As such, folktales and legends positively reinforce shared worldviews and a sense of inclusion, serving to locate communities in both space and time. By contrast, Gothic landscapes evoke anxieties and uncertainties arising from their otherness and their orientation towards the unknown. Gothic's affect is frequently located in a loss of control and comprehension as protagonists and, vicariously, readers journey beyond the boundaries of the known, shifting them into a fantasised space (and, certainly in earlier Gothic texts, fantasised time). It is the unreality of this distancing that created the imaginative space in which to safely indulge in the breaking of cultural taboos, to liberate fears and desires that are usually marshalled by rationalisation and social convention.

\section{Spring-heeled Jack: Connections and Distinctions}

To ground these rather abstract, introductory reflections on Gothic and folkloric narratives, and to demonstrate their complex, nineteenth-century interplay of influences, we will now turn to the urban legend of Spring-heeled Jack. First appearing in villages on the southern fringe of London in autumn 1837, he was initially described as a ghostly white bull. As he drew closer to the city, local rumour described him as a ghost, 'an imp of the "Evil One", a figure 'clad in mail' and dressed 'as a bear'. ${ }^{15}$ At Hampton Court he appeared as 'an unearthly warrior clad in armour of polished brass, with spring shoes and large claw gloves' ${ }^{16}$ Gradually becoming aware of the developing story, journalists reported local gossip about attacks at night, some of which had supposedly caused predominantly female 
victims to lose their minds or even die of fright. In one attack on a carpenter in Isleworth an armoured, clawed figure tore the man's clothes to ribbons. ${ }^{17}$ Given the localities which he haunted, the press initially dubbed him 'The Suburban Ghost'. After being mentioned by the Lord Mayor of the City of London in early January 1838, the metropolitan press ran stories on his appearances, giving him the far catchier moniker 'Spring-heeled Jack' in the process. ${ }^{18}$

The most widely reported account involved an attack on eighteen year old Jane Alsop, in February 1838. Giving testimony before magistrates, she told how he had turned up at her family home near the village of Bow the previous night. At a quarter to nine there had been 'a violent ringing at the gate in front of the house'. When Jane went to the gate the caller said "For God's sake bring me a light, for we have caught Spring-heeled Jack here in the lane." Jane did as requested, and upon handing the man a candle he threw off his large cloak and revealed 'a most hideous and frightful appearance [...] his eyes resembled red balls of fire.' She briefly saw that he wore a helmet and tight-fitting 'white oil-skin' clothes before he spat blue and white flames at her. He then grabbed Jane, tearing her gown with what she said were metallic claws. She reached the front door of the house before he caught her again, this time tearing at her neck and arms. Jane's older sister eventually pulled her inside the house, locking the attacker outside. ${ }^{19}$

Similar tales of a fire-breathing attacker and the random scaring of servants and pedestrians continued in London until spring, when he left the capital and began to appear all around the country. ${ }^{20}$ In the provinces, and for much of the rest of the century, Spring-heeled Jack gradually transformed from a clawed, fire-breathing, vicious assailant to an annoying prankster who sought to frighten but otherwise left his victims unmolested. Following a brief revival of Spring-heeled Jack's name and antics in the 1870s, he became overshadowed by Jack the Ripper from 1888. Transitioning from a specific individual to a more diffused 'type 
of Spring-heeled Jack' figure, his sporadic accounts limped on into the twentieth century, with supposed late appearances in Everton in 1904 and Warrington in $1920{ }^{21}$

Although operating as an expression of contemporary folklore, Spring-heeled Jack presented a number of Gothic connections. While obviously evoking the Gothic's cultural lexicon of monstrosity, his accounts also foreshadowed its Victorian shift towards a modern urban environment, and echoed its emphasis on affective responses and heightened emotions. In Spring-heeled Jack we see an example of early Victorian folklore being generated in the wake of the first wave of Gothic literature, and therefore open to being inflected by or through its lens. As will be suggested below, the transmission between folklore and the Gothic was not unidirectional; while the literary Gothic appropriated earlier oral tales, so too did this folkloric figure resonated with Gothic tropes and influences.

Whether witnesses, victims or mere gossips, Londoners readily drew upon monstrous folkloric types, including the evil trickster, ghosts, devils and were-beasts. Yet their descriptions also harked back to earlier Gothic literature's spectres and demons, and the two influences cannot be easily untangled. If, as the press suggested, this was an elaborately costumed prank, it was clearly intended to evoke associations with various forms of Gothic and folkloric monstrosity. Although journalists rejected Spring-heeled Jack's seemingly supernatural elements, their alternative interpretation nevertheless resonated with earlier Gothic literature. Newspapers claimed the scare was the result of a wager by a number of people belonging to 'the higher ranks of life' to appear in villages around London dressed as 'a ghost, a bear, and a devil'. On $14^{\text {th }}$ January 1838 the Examiner claimed 'the bet is that the monster shall kill six women in some given time', and that 'some individual ("gentleman" he has been designated) drives about with a livery servant in a cab, and, throwing off a cloak, appears in these frightful forms'. ${ }^{22}$ In this way, journalists evoked Gothic literature's malevolent aristocratic villains and its social critique born of a revolutionary era. Emerging 
before a wider metropolitan audience as a contemporary news story, Spring-heeled Jack evolved into a developed character beyond a mere urban ghost. The application of his name to multiple sightings served to conflate various Gothic entities (devil, beast, ghost and human predator) into a mysterious, mercurial, and unique monster.

Press reports on Spring-heeled Jack's monstrous appearances in London presaged the Gothic's move into the modern city in the Victorian period. While the capital had previously suffered strange attackers and ghostly pranksters such as the London Monster and the Hammersmith Ghost, Spring-heeled Jack's rich conflation of monstrosity largely eclipsed these more prosaic figures. ${ }^{23}$ In the manner of folkloric accounts, his appearances and bizarre attacks caused formerly familiar locales to obtain new and altered associations, generating a Gothic de-familiarising of the known. As Aguirre notes, 'not least among [Gothic's] terrors is the fact that characters cannot quite tell it from their own world: it is part of and yet profoundly alien to the human realm.' (312). In themselves, the mundane streets and lanes of Spring-heeled Jack's early appearances lacked the psychological resonances of Gothic's incarcerating edifices, its haunting ruins, or tangled forests. Yet it was their very mundanity that helped generate the jarring dissonance caused by his startling presence. As later works such as G. W. M. Reynolds' hugely popular The Mysteries of London (1844-48) demonstrated, the urban Gothic's power and thrill lay in relocating the Gothic from medieval or early modern Catholic Europe to nineteenth-century London. Collapsing the Gothic's previously safe temporal and geographical distance, the modern city became 'the loci for mystery and terror $[\ldots]$ the dark alleyways of cities were the gloomy forests and subterranean labyrinths' of earlier Gothic works (Botting, 123). ${ }^{24}$ The discord created by such a shift was voiced by John Cowen, the Lord Mayor of the City of London. When first informed about 'the demon' who would become known as Spring-heeled Jack, he declared such an entity 'was not calculated for the meridian of London'. ${ }^{25}$ 
However, rather than being an expression of older folkloric beliefs, a revenant from the past, Spring-heeled Jack can be understood as a manifestation of contemporary urban concerns. Legends may draw upon historical and fantastical elements but they 'can also express the anxieties and insecurities caused by rapidly changing society, fears of the unknown [...] and other important matters of social psychology.' (Valk, 169). Speaking to contemporary uncertainties about threats and the anonymous strangers who populated growing cities beyond less static, less tightly bound urban communities, Spring-heeled Jack was a new folklore for the self-consciously modern context of the nineteenth-century city. Whereas folklore collections were typically orientated towards the past, Spring-heeled Jack resonated more with the Gothic's tendency to respond to the underlying anxieties of the age, hence its ongoing ability to adapt and survive.

Of course, the Gothic is more than its monsters. It is not reliant purely on the content of its narrative, but also the affective response it seeks to generate in the reader. Beyond its familiar spatial and supernatural tropes, Bacon has claimed the 'need to shock, jolt, unnerve, or even produce awe is at the core of the Gothic in its many forms' (1). This affective dimension was evident in the press reporting on Spring-heeled Jack's activities in 1837 and 1838. These reports gave much attention to the way his victims responded to such encounters, with some so terrified they had supposedly lost their wits. As The Times reported on $9^{\text {th }}$ January 1838 , when a servant girl was confronted by the 'dreadful [...] spectre', she 'immediately swooned, and has never from that moment been in her senses'. Two other 'ladies' had lost their senses and were 'not expected to recover'. Two days later an 'inhabitant of Stockwell' made (unconfirmed) claims that some of Spring-heeled Jack's victims had actually died of fright. When a figure 'enveloped in a white sheet and blue fire' confronted the daughter of Plutarch Dickenson Esq. of Dulwich, on her way home from a party she too was left 'nearly deprived of her senses' and 'lying in a very dangerous state' of health. ${ }^{26}$ As such, Spring-heeled Jack's 
assaults were psychological as much as physical, and the stories generated a narrative of extreme emotional and mental responses from victims, propagating associations between mental instability and the irrationalism that this strange entity symbolised. In doing so, these press accounts align with Aguirre's view of the Gothic's operation, one which is not focussed on the supernatural or the numinous itself, but rather the affective response to encounters with the numinous (299).

Despite these similarities and connections, there were also notable distinctions from the Gothic too. Like most folkloric tales, Spring-heeled Jack's legend was not shaped or defined by a single author or narrative, but arose from a miasma of rumour and speculation. As the Morning Herald reported on $10^{\text {th }}$ January 1838 , 'Although the stories were in everybody's mouth, no person who had actually seen the ghost could be found.' The reporter declared that when he located named victims 'they immediately denied all knowledge of it, but directed him to other persons whom they had heard had been ill treated, but with them he met with no better success.' Despite its attempts to track accounts to their source, to give some coherence to the confused snippets of gossip and to offer editorial reflections on the scares, the metropolitan press proved unable to assert any authorial direction or authority. The press merely added a range of voices to the multitude they recorded, their tone and stances fluctuating considerably, sometimes referring to the scares as 'outrages', even a '“Springheeled Jack" mania', at others, merely as 'mischievous pranks' ${ }^{27}$ With both novel and newspaper reading increasing in the nineteenth century, Benedict Anderson has noted, 'Reading a newspaper is like reading a novel whose author has abandoned any thought of a coherent plot' ${ }^{28}$ The media that conveyed Spring-heeled Jack's narrative played a role in shaping the content, context and presentation of Spring-heeled Jack's earliest appearances without providing meaning. While the press arguably fostered a sense of a virtual metropolitan community, its operation was narrowed by editorial control and, lacking the 
emotional connection with specific localities, its many voices were always more remote than those that circulated in communal oral cultures.

Yet this fragmentary and often contradictory narrative can also make us question whether Spring-heeled Jack even operated as folklore at the time of his first appearances. While folktales are organic and performative, defined by omissions and additions at each telling, the press reports suggest that, beyond the intriguing name, there was little of core consistency in the multiple tellers' widely varying accounts. His aetiology, nature, purpose, even his very existence was uncertain. Rumour granted him a shape-shifting quality, emphasising the subjectivity of both encounters and the interpretations that arose from them. Recorded as a series of disparate mono-episodic incidences, press accounts and the oral tales they alluded to offered fragments of stories that did not coalesce, that lacked both structure and meaning. Unlike Gothic tales, folkloric narratives tend to inform and instruct as they entertain, delivering messages, reinforcing values and boundaries through warning against the consequences of crossing them. Spring-heeled Jack offered no coherent message. The legend was only able to gather a degree of coherence in retrospect, and only really gained an identifiable narrative, albeit a largely formulaic one, in his penny dreadful serials. ${ }^{29}$

\section{Enacted Gothic and Penny Dreadful Literature}

Spring-heeled Jack's Gothic and folkloric dimensions have to contend with a third, rather unruly element, that of contemporary experiential realities. In the press reports above Springheeled Jack was first and foremost a contemporary news story. His was one of those unusual historical moments when the Gothic appears to break from the bounds of fiction and spill 
over into the real world. A similar sense was evoked by Jack the Ripper and, it has been argued, by the experience of conditions in London during the Second World War. ${ }^{30}$ Twentyfirst century cases might include Armin Meiwes, the 'Rotenburg Cannibal' who killed and ate his voluntary victim, and Josef Fritzl who incarcerated his daughter in a concealed room for twenty-four years and whose sexual abuse led to her giving birth to seven children. Here the Gothic intrudes into the real, its resonances informing our simultaneous attraction to and repulsion from such horrific realities. Taking into account this trinary between the Gothic, folklore and the 'real', and riffing on what Maria Beville has called 'lived Gothic', that is Gothic as 'a way of living, a way of seeing [...] a way of remembering', this article terms this relationship the enacted Gothic. ${ }^{31}$

The enacted Gothic is performative, both in the physical acting out of what was more usually experienced vicariously within the pages of a literary text (or folkloric tale), and, in the case of Spring-heeled Jack, the seeming knowingness with which those tropes were articulated. As has already been suggested, this closeness between fiction and real life manifestations may have evolved from disguised pranksters consciously attempting to mimic folkloric monsters. Alternatively, or in addition, such frightening encounters may have been subsequently interpreted and expressed by victims, witnesses or gossips through such a lens, drawing upon known and pre-existing story patterns and tropes to articulate those baffling experiences. That story framework was predominantly folkloric but, as seen above, it had Gothic inflections too. The perpetually unresolved tension between the real and the imaginary prevented Spring-heeled Jack from being fully appropriated into the fictionally-contained realm of Gothic literature. While his contemporary accounts were coloured by elements of both folkloric and Gothic narratives, his appearance in the streets of London served to negate the Gothic's urge towards unreality, while failing to provide the coherence or communally instructive purpose of folktales. 
The enacted Gothic raises the question of whether Gothic's poetics can only work within the confines of a fictional world, for crossing over into the experiential world problematizes the vicarious thrills and pleasure derived from such texts. Press reports on scattered rumour held readers at least twice removed from the experiences of Spring-heeled Jack's victims, but the potential for an encounter brought that distance uncomfortably close when compared with the monsters that were safely contained within overt fictions. This fear seemed to have been widespread in London through the autumn and winter of 1837-38. Stating a frequently cited observation, on $14^{\text {th }}$ January 1838 , the Examiner reported that women 'feared to walk abroad after nightfall, in consequence of the molestations of a ghost or monster to which they were exposed'. ${ }^{32}$ Demonstrating the influence of the 'real' within the enacted Gothic, oral rumour and the press reports through which it was more widely circulated studiously avoided expressing any of the sadistic or pornographic delight that Gothic authors and readers took from the exploits of the monster or the suffering of the victim. In incidents where sexual assault was suggested, the press made only vague allusions to female victims being 'ill treated' ${ }^{33}$

In outlining his 'grammar' of the Gothic, Aguirre proposes that it is defined by a meeting of or transference between two ontological zones; the mundane and the numinous. ${ }^{34}$ Yet in his formulation, even the mundane is contained within a fiction, and the 'normal' world is still a mimetic one. It may help serve as a benchmark against which the alien nature or intrusion of the numinous can be gauged, but experiential reality does not tend to be so rigid or accommodating; reality, as the tales swirling around Spring-heeled Jack suggest, could be far stranger than fiction. His real world appearances (or at least fervent rumours of such) seemed to disrupt the boundaries that kept the Gothic contained in a purely fictional domain. As such, the enacted Gothic possesses a carnivalesque quality, for notions of 'normality' and 'reality' were called into question through Spring-heeled Jack's transgressive performances. 
However brief, a disturbing sense of 'otherness' (supernatural or otherwise, depending on the interpretation) had erupted into the familiar rhythms and spaces of the capital.

Yet mindful of the folkloric element within this dynamic, one notes that when Gothic horrors break into the real world there is a strong tendency for them to accumulate folkloric accruals that draw them 'back' toward more overt fictional representations. Often, the exceptionalism of the actions or crimes being perpetrated causes such grim realities to be expressed in terms that distance them, transposed behind a gloss of Gothic fictionality with which they appear to resonate. Even the gruesome crimes of Jack the Ripper have acquired a degree of folkloric detachment, with speculation about the killer's identity and motives breeding a host of conspiracy theories that have gradually disconnected the murderer from reality and, in doing so, have made it easier to relocate him into the contained world of overt fiction. ${ }^{35}$ This coating of realities in what has been termed the 'endemic fakery' of the Gothic, a quality that 'exaggerates and intensifies its fictionality' (Warwick, 12), suggest folkloric and Gothic narrative tropes may not have simply been drawn upon to structure and make sense of Spring-heeled Jack's bizarre actions and appearances. Instead, they served to distance him from reality, to re-create him along the lines of familiar storytelling templates, be they folkloric or Gothic, and in doing so render him less real.

The trinary elements within the enacted Gothic diminished somewhat when Springheeled Jack's penny dreadfuls of the 1860s and 1870s reimagined his 1838 appearances, time having distanced them into folklore. These publications were heavily indebted to earlier Gothic literature for many of their narrative tropes; the intrusion of the apparently supernatural and diabolical, patriarchal villains, young female victims, the misunderstood monster. Penned as rollicking adventures for a predominantly juvenile readership, they often toyed with the Gothic's gloomy aesthetic but never allowed it to dampen the narrative's exuberant energy. The penny dreadful serial, Spring-Heeled Jack; The Terror of London, was 
published in 1867-68. Marking a radical departure from his folkloric characterisation, it reinvented Spring-heeled Jack as a costumed avenger who flouts the law to defend the weak and punish the wicked, often using terror as much as violence to defeat his foes. Echoing the earlier press accounts, he wore 'a repulsive-looking mask', clawed gloves, and spring-heeled boots. In one episode he terrifies a drunken bully by appearing before him, his head and body glowing 'with a blue, phosphorescent fire'. Referencing Spring-heeled Jack's diabolical image and his theatrical use of fire and phosphorous in the initial London appearances, the roguish hero weaponises Gothic scares to punish and traumatise. ${ }^{36}$

In 1878-79 the Boy's Standard ran a serial similarly entitled Spring-Heeled Jack; The Terror of London. While the story contained violence and scares it was more focussed on Gothic intrigue and betrayal. Framed as a summary of a diary belonging to the original Spring-heeled Jack, it offers a re-interpretation of his 1838 appearances. The story's plot and narrative tropes are again heavily indebted to earlier Gothic literature. A disinherited young marquis is usurped by a corrupt uncle and the family lawyer following the death of his parents at sea. The rightful heir's search for justice and his saving of a young woman from a Gothic villain father duplicate a narrative path taken by many cheap fictional protagonists. Although allusions to ghosts, guilt and moral justice abound, the serial remained more focussed on daring action than macabre horror. ${ }^{37}$

In both serials Spring-heeled Jack was transformed through a Radcliffean-styled rationalisation of the supernatural, a development that diminished him as a Gothic monster but enabled his repositioning as the youthful, roguish hero common to many penny dreadful serials. A generation on from the original scares, these serials allowed the disturbing ambiguity of the real monster in the metropolis to be safely contained within literary texts, emptied of real threat by being confined to the formulaic plots of penny dreadful authors. What had once been potentially close had been removed by this Gothic literary transition; 
anxiety had been transformed into knowing play, a once immediate threat changed into safely remote references, Gothic and overtly fictional.

However, Spring-heeled Jack did not remain completely contained within literary fiction. His shift from a singular individual to a label for anything strange or inexplicable led to sporadic press accounts in the 1870s and 1880s, although the swift, pale figures they described bore little resemblance to the fire-breathing demon that had once terrorised London. The 1870s saw a revival of sightings in London, Sheffield, and the Aldershot and Colchester Army Bases. ${ }^{38}$ Unlike the penny dreadfuls where justice was done and all was put right, in the real world Spring-heeled Jack could not be bent to narrative expectation. While the individual who caused consternation at the Colchester Army base eventually received a bayonet wound to the leg, his scares and attacks tended to go unpunished. ${ }^{39}$ In cases where a culprit was apprehended, they were never thought to be the actual Spring-heeled Jack, just foolish imitators. ${ }^{40}$

The interaction between folklore, literature and real appearances continued up to Springheeled Jack's eventual disappearance. This is best demonstrated by his supposedly superhuman ability to leap great heights or huge distances. The penny dreadfuls had greatly exaggerated the initial press reports' modest and passing references to his swiftness or athleticism. In turn, this literary distortion filtered back into how he was remembered in folkloric accounts. By one of his last appearances in Everton in 1904 it was claimed he had been seen leaping houses and springing down streets. ${ }^{41}$

Although a Gothic scholarly interest in and engagement with folkloric narratives seems long overdue, this article has urged a more nuanced and problematized investigation beyond the obvious and identifiable narrative tropes and surface correlations. Given that a Gothic aesthetic seems to have become so ubiquitous in our visual media-driven twenty-first century 
culture, it is perhaps too easy for scholars to recognise or want to impose those connections. As demonstrated through this brief study of the legend of Spring-heeled Jack, one can certainly find significant meeting points between folkloric and Gothic traditions and narratives, although neither neatly followed the other. Spring-heeled Jack's printed accounts and cultural expressions variously involved a traversing between, and a blending of Gothic and folkloric influences. Yet we should focus as much on the points of departure as on the areas of resonance, the way in which the Gothic does not fit easily with folklore's nature or communal purpose, the mechanics or tone of its narratives, its differing audiences and mode of storytelling (collective and performative, rather than solitary), and the contexts in which those different types of stories were told; all shape how a narrative is presented, structured, consumed, and interpreted.

This article has used its study of Spring-heeled Jack to connect literary Gothic cultures to historicised and localised folkloric traditions. In doing so, it seeks to encourage an expansion of the types of 'texts' that Gothic scholarship may consider drawing upon and investigating. Its reflections on narrative connections and differences, and on the enacted Gothic, seek to facilitate a more nuanced examination of folklore by Gothic scholars. Yet it has also sought to maintain the Gothic's coherence by digging beyond shared tropes to consider how Gothic and folkloric narratives differ. It is precisely because it is a literature of liminality that the Gothic must maintain a sense of what it is and is not, what it does and does not, and where those boundaries can be usefully located. 


\section{Notes}

${ }^{1}$ Manuel Aguirre, 'Gothic Fiction and Folk-Narrative Structure: The Case of Mary Shelly’s Frankenstein', Gothic Studies, 15:2 (2013), p. 14. See also Aguirre, 'Thick Description and the Poetics of the Liminal in Gothic Tales', Orbis Litterarum, 72:4 (2017), pp. 294-317. Further references to this second publication are given in the text.

${ }^{2}$ For more on this issue of Gothic's objectivity and subjectivity see Alexandra Warwick, 'Feeling Gothicky,' Gothic Studies, 9:1 (2007), p. 6. Further references to this are given in the text.

${ }^{3}$ For more on the interaction between oral and literary cultures see Andy Wood, The Memory of the People: Custom and Popular Senses of the Past in Early Modern England (Cambridge: Cambridge University Press, 2013), pp. 247-86, and Sasha Handley, Visions of an Unseen World: Ghost Beliefs and Ghost Stories in Eighteenth-Century England (London: Pickering and Chatto, 2007), pp. 49-79.

${ }^{4}$ See Vito Carrassi, 'Theorizing, collecting, archiving, reviving: the lives (or life?) of folklore', Folk Life, 55:1 (2017), pp. 1-11. For more on the growth of folklore scholarship see Timothy Baycroft and David Hopkin (eds), Folklore and Nationalism in Europe During the Long Nineteenth Century (Leiden, Brill, 2012).

${ }^{5}$ See also Fred Botting, Gothic, (London: Routledge, 1996), p. 16, and Jason Marc Harris, Folklore and the Fantastic in Nineteenth-Century British Fiction (Aldershot, Ashgate, 2008), pp. 19-20. Further references to Botting are given in the text.

${ }^{6}$ See, for example, John Harland and T.T. Wilkinson, Lancashire Folk-Lore (London: Frederick Warne and Co., 1867), Charles Hardwick, Traditions, Superstitions, and Folklore (Manchester: A. Ireland, 1872), William Henderson, Notes on the Folk-lore of the Northern 
Counties of England and the Borders (London, Folklore Society, 1879), and M. H. James, Bogie Tales of East Anglia (Ipswich, Pawsey and Hayes, 1891).

${ }^{7}$ To date, Ecogothic's engagement with landscape continues to privilege literary texts over folkloric narratives. See, for example, Andrew Smith and William Hughes (eds), Ecogothic (Manchester: Manchester University Press, 2013).

${ }^{8}$ See Stith Thompson, Motif Index of Folk Literature, 6 vols (Bloomington, Indiana University Press, 2001) - https://archive.org/details/Thompson2016MotifIndex

${ }^{9}$ Simon Bacon, The Gothic: A Reader (Oxford: Peter Lang, 2018), p. 1.

${ }^{10}$ For an emphasis on exploring spatially and historically specific examples of the Gothic as a counter to sweeping, ahistorical psychologising see Roger Luckhurst, 'The Contemporary London Gothic and the Limits of the "Spectral Turn", Textual Practice, 16 (2002), pp. 52746.

${ }^{11}$ Sara Wasson, Urban Gothic of the Second World War: Dark London, (Basingstoke, Palgrave, 2010), p. 2.

${ }^{12}$ There has been some opposition to reductive Freudian psychoanalytical approaches in Gothic scholarship. See, for example, Wasson, Urban Gothic, pp. 25-26, Warwick, Feeling Gothicky, pp. 9-10, and Markman Ellis, The History of Gothic Fiction (Edinburgh, Edinburgh University Press, 2000), p. 13.

${ }^{13}$ David Punter, Literature of Terror, Volume 1 The Gothic Tradition, $2^{\text {nd }}$ edn (London: Routledge, 1996), p. 2. Further references to this are given in the text. For more on the political and socio-economic realities that inform folktales and fairy tales see Jack Zipes, Breaking the Magic Spell: Radical Theories of Folk and Fairy Tales $2^{\text {nd }}$ edn (Lexington, University Press of Kentucky, 2002), pp. 23-46, and Eugen Weber, 'Fairies and Hard Facts: The Reality of Folktales', Journal of the History of Ideas, XLII (1981), pp. 93-113. 
${ }^{14}$ Ulo Valk, 'Folk and the Others: Constructing Social Reality in Estonian Legends' in Terry Gunnell (ed.), Legends and Landscape (Reykjavik, University of Iceland Press, 2008), p. 159. Further references to this are given in the text. See also Terry Gunnell, 'Legends and Landscape in Nordic Countries', Cultural and Social History, 6 (2009), 305-22.

${ }^{15}$ Morning Chronicle, $10^{\text {th }}$ and $11^{\text {th }}$ January 1838.

${ }^{16}$ Morning Chronicle, $10^{\text {th }}$ January 1838.

${ }^{17}$ Ibid.

${ }^{18}$ The Times, $9^{\text {th }}$ January 1838 , and Penny Satirist, $20^{\text {th }}$ January 1838.

${ }^{19}$ Morning Chronicle, $22{ }^{\text {nd }}$ February 1838.

${ }^{20}$ See Morning Herald, $27^{\text {th }}$ February 1838 , Morning Post, $7^{\text {th }}$ and $13^{\text {th }}$ March 1838 , and The Times, $14^{\text {th }}$ April 1838 .

${ }^{21}$ For more details see Karl Bell, The Legend of Spring-heeled Jack - Victorian Urban

Folklore and Popular Cultures (Woodbridge, Boydell and Brewer, 2017), pp. 19-46.

${ }^{22}$ The Times, $9^{\text {th }}$ January 1838 , and the Examiner, $14^{\text {th }}$ January 1838.

${ }^{23}$ See Jan Bondeson, The London Monster: Terror on the Streets in 1790 (Stroud, 2003), and Owen Davies, The Haunted - A Social History of Ghosts (Basingstoke, Palgrave, 2007), pp. 21-22.

${ }^{24}$ Spring-heeled Jack's Gothicised othering of metropolitan spaces was subsequently echoed by journalists, social investigators and fiction writers. See Jamieson Ridenhour, In Darkest London: The Gothic Cityscape in Victorian Literature (Lanham: Scarecrow Press, 2013).

25 The Times, $9^{\text {th }}$ January 1838.

${ }^{26}$ See Morning Chronicle, $11^{\text {th }}$ January 1838, and Morning Post, $7^{\text {th }}$ and $13^{\text {th }}$ March 1838.

${ }^{27}$ See John Bull, $25^{\text {th }}$ February 1838, Morning Post, $13^{\text {th }}$ March and $26^{\text {th }}$ May 1838.

${ }^{28}$ Benedict Anderson, Imagined Communities: Reflections on the Origin and Spread of Nationalism (London: Verso Books, 1991), p. 33. 
${ }^{29}$ See, for example, All the Year Round, $9^{\text {th }}$ August 1884, p. 345-49, Notes and Queries $10^{\text {th }}$ Series, $30^{\text {th }}$ March 1907, p. 256, and Elizabeth Villiers, Stand and Deliver: The Romantic Adventures of Certain Gentlemen of the High Toby, Their Times, Their Associates, Friends and Victims (London, 1928), pp. 238-52.

${ }^{30}$ See Judith Walkowitz, City of Dreadful Delight - Narratives of Sexual Danger in LateVictorian London (London, Virago, 1992), pp. 196-97, Andrew Smith, Victorian Demons Medicine, Masculinity and the Gothic at the Fin-de-Siecle (Manchester, Manchester University press, 2004), pp. 67-94, and Wasson, Urban Gothic, p. 4, 11-15.

${ }^{31}$ Lorna Piatti-Farnell and Maria Beville (eds), The Gothic and the Everyday: Living Gothic (Basingstoke: Palgrave, 2014), p. 54.

${ }^{32}$ For similar accounts see The Times, $11^{\text {th }}$ January 1838, and the Morning Chronicle, $10^{\text {th }}$ January and $28^{\text {th }}$ February 1838.

${ }^{33}$ See, for example, the Era $11^{\text {th }}$ April 1841.

${ }^{34}$ See Manuel Aguirre, 'A grammar of Gothic: Report on a research project on the forms of the Gothic genre', Romantic Textualities: Literature and Print Culture, 1780-1840, 21 (2013), pp. 126-27 - http://www.romtext.org.uk/files/2014/07/rt21_n07.pdf

${ }^{35}$ See Alan Moore and Eddie Campbell, From Hell (1999), and Alexandra Warwick and Martin Willis (eds), Jack the Ripper: Media, Culture, History (Manchester, Manchester University Press, 2007). Spring-heeled Jack has similarly resurfaced in literary form in Mark Hodder's The Strange Affair of Spring-heeled Jack (2010), and David Hitchcock's Springheeled Jack (2014).

${ }^{36}$ Spring-Heeled Jack: The Terror of London (1867-68), pp. 3-4 and 23.

${ }^{37}$ Anon, Spring-heeled: The Terror of London. (London, 1878).

${ }^{38}$ See Bell, Spring-heeled Jack, pp. 37-40.

${ }^{39}$ See Lloyd's Weekly Newspaper, $29^{\text {th }}$ December 1878. 
${ }^{40}$ For earlier cases of Spring-heeled Jack imitators, see the Examiner, 25 ${ }^{\text {th }}$ March 1838 , Morning Post, $4^{\text {th }}$ April 1838.

${ }^{41}$ See News of the World, $25^{\text {th }}$ September 1904, and also Liverpool Daily Post, $25^{\text {th }}$ January 1967 and Liverpool Echo, $19^{\text {th }}$ May 1967. 